\title{
E3 Ubiquitin-Protein Ligase TRIM33
}

National Cancer Institute

\section{Source}

National Cancer Institute. E3 Ubiquitin-Protein Ligase TRIM33. NCI Thesaurus. Code C97860.

E3 ubiquitin-protein ligase TRIM33 (1127 aa, $123 \mathrm{kDa})$ is encoded by the human TRIM33 gene. This protein is involved in protein ubiquitinylation. 